\title{
Influence of Two Insect Growth Regulators on Chitinase Activity
}

\author{
Seham M. Ismail ${ }^{1}$ and N. Shaker ${ }^{2}$ \\ ${ }^{1}$ Central Laboratory of Pesticides, Sabahia, Alexandria, A.R.C., Egypt \\ ${ }^{2}$ Pesticide Chemistry Dept., Fac. Agric., Alex. Univ., Egypt
}

Received on: $18 / 11 / 2015$

Accepted: $31 / 12 / 2015$

\section{ABSTRACT}

Toxicity of two insect growth regulators (IGRs) (lufenuron and hexaflumuron) against two larval instars of cotton leafworm Spodoptera littoralis, laboratory and field strains were determined. Chitinase activity in the two strains also was investigated. Results revealed that, $2^{\text {nd }}$ instar larvae were more sensitive than $4^{\text {th }}$ instar larvae to both insecticides. The sensitivity of chitinase activity was measured by $\mathrm{I}_{50}$ values. The $\mathrm{I}_{50}$ values of lufenuron were 0.31 , and $0.64 \mu \mathrm{M}$ for lab and field strains of $S$. littoralis $2^{\text {nd }}$ larvae respectively, while $\mathrm{I}_{50}$ values were 0.44 , and $0.75 \mu \mathrm{M}$ for lab and field strains of S. littoralis $4^{\text {th }}$ larvae respectively. The hexaflumuron were 0.57 , and $0.76 \mu \mathrm{M}$ for lab and field strains of S. littoralis $2^{\text {nd }}$ larvae respectively, the $\mathrm{I}_{50}$ values were 0.65 , and $0.81 \mu \mathrm{M}$ for lab and field strains of $S$. littoralis $4^{\text {th }}$ larvae respectively. Also, chitinase enzyme kinetic parameters, as Michaelies-Menten Kinetics $\left(K_{m}\right.$ and $\left.V_{m a x}\right)$ values and the inhibition constant $\left(\mathrm{K}_{\mathrm{i}}\right)$ were determined. The obtained data proved that lufenuron and hexaflumuron compounds are competitive inhibitors of chitinase activity. Results indicated that, the IGRs have shown high potentiality against larvae of $S$. littoralis, so, these IGRs may be recommended for S. littoralis larvae control, it could be concluded that the use of IGRs instead of conventional hazardous insecticides; may avoid increasing selection pressure of $S$. littoralis populations to conventional insecticides, hazard effects on human health, environmental components and natural enemies, IGRs may play an important role in future insect pest management programs.

Key words: Chitinase- $S$. littoralis - insect growth regulators (IGRs).

\section{INTRODUCTION}

The development of multiple insecticide resistance in field strain of the Spodoptera littoralis to several insecticides has been recorded by several investigators. Due to severe applications of insecticides for the control of $S$. littoralis larva instars, which are the most destructive stages of the insect on cotton and vegetable crops, the larval stages have become extremely tolerant to the action of pesticides (Ware 2000 and Temerak 2002). So the need to develop novel alternatives or functional combinations of pest control techniques is emphatically a product of this decade and many sources for alternative pesticides were found such as insect growth regulators (IGRs) compounds which are considered nowadays one of the mainly component of IPM program. Term IGRs describe a new class of bio-rational compounds, this group are active against larvae of many lepidopterous species (Fisk \& Wright 1992; Schneider et al., 2003, and Sandeep \& Bhamare 2006).

Therefor the present work was conducted to study the efficiency of two IGRs (lufenuron and hexaflumuron) upon the $2^{\text {nd }}$ and $4^{\text {th }}$ larval instar of $S$. littoralis, and describe the development of biochemical assay system for measuring the sensitivity of chitinase enzyme to two IGR (lufenuron and hexaflumuron), in laboratory and field strains.

\section{MATERIALS AND METHODS}

\section{Test insects:}

Susceptible laboratory strain of cotton leafworm, Spodoptera littoralis was provided by central lab of pesticides, Agricultural Research Center (ARC) Cairo, Egypt which was reared for several years on artificial diet under standard laboratory conditions of $27 \pm 2{ }^{\circ} \mathrm{C}$ and $65-70 \% \mathrm{RH}$.

Field strain of cotton leafworm, Spodoptera littoralis egg masses were collected from cotton fields at Abeis area Alexandria, governorate Egypt. The $2^{\text {nd }}$ and $4^{\text {th }}$ larval instars were chosen for bioassay and biochemical assessment.

2. Test insecticides:

Lufenuron (Match, 5\% EC), and hexaflumuron (consult, 5\% EC), were supplied by Syngenta.

3. Bioassay tests:

3.1. Toxicity of the tested IGRs against $S$. littoralis:

Lufenuron and hexaflumuron were bioassayed against the $2^{\text {nd }}$ and $4^{\text {th }}$ larvae of $S$. littoralis. The castor leaves were dipped in different concentrations of the tested IGRs. Lufenuron and hexaflumuron concentrations were prepared in distilled water. Treated and control leaves plants were air-dried for $3 \mathrm{hrs}$, the treated leaves were placed in clean glass container at the laboratory conditions of $\left(27 \pm 2{ }^{\circ} \mathrm{C}\right)$ and $65-70 \% \mathrm{RH}$, ten larvae (lab and field strains) were used for each test with three replicate at least. Number of alive and dead larvae per replicate was 
counted 24, and $48 \mathrm{hr}$, after treatment Concentrations-mortality percentage were calculated and corrected for natural death according to Abbott equation (Abbott, 1925). LC $_{50}$ values were calculated and statisticaly and analysed by using the probit-analysis method of Finney (1971).

\section{Biochemical studies:}

\subsection{Chitinase preparation and activity assay:}

Chitinase was prepared from Spodoptera littoralis $2^{\text {nd }}$ and $4^{\text {th }}$ instars larvae (lab and field strains) according to the method of Deul et al. (1978). Larvae homogenate was prepared in $10^{3} \mathrm{M}$ Clelands' reagent (dithiotheritol, DTT) $(\mathrm{v} / \mathrm{w}=2)$, centrifuged at $12.000 \mathrm{~g}$ for $15 \mathrm{~min}$. Then an equal volume of saturated ammonium sulfate solution was slowly added to the supernatant. After stirring for 1 $\mathrm{hr}$, the suspension was centrifuged at $10.000 \mathrm{~g}$ for $10 \mathrm{~min}$. The precipitate was washed with halfsaturated ammonium sulfate solution and recentrifuged. Then it was suspended in a small volume of water, followed by dialysis for $20 \mathrm{hr}$ at 0 $2{ }^{\circ} \mathrm{C}$.

The chitinase activity measurements were done according to the method reported by Reissig et al. (1955), which modified by Andrew et al., (1982), using sodium acetate buffer instead of tris-HCl buffer and wave-leangth of $416 \mathrm{~nm}$ instead of 544 nm. $25 \mu 1$ of chitin $(20 \mathrm{mg} / \mathrm{ml}), 100 \mu$ l of enzyme preparation were used and $225 \mu 1$ of sodium acetate (pH 4.5) in total volume $350 \mu 1$. The enzyme substrate mixture was incubated at $35^{\circ} \mathrm{C}$ for $60 \mathrm{~min}$, then the reaction was stopped by adding $100 \mu 1$ of $0.8 \mathrm{M}$ borate buffer (pH 10.0) followed by determination of n-acetylglucoseamine by method of Reissig et al., (1955) by adding $1.5 \mathrm{ml}$ of $\mathrm{p}$ dimethyl amino benzaldhyde (DMAB, reagent). The samples were incubated in shaker water bath at 35 ${ }^{\circ} \mathrm{C}$ for $20 \mathrm{~min}$ and were measured spectrophotometrically at $\lambda 412 \mathrm{~nm}$.

The protein content in prepared homogenates of $S$ littoralis was assayed by the method of Lowery et al. (1951) at $\lambda 750 \mathrm{~nm}$ using Bovine Serum Albumin (BSA) as a standard protein.

\subsection{In vivo inhibition of chitinase activity}

The inhibition percentage of chitinase activity was determined in the $2^{\text {nd }}$ and $4^{\text {th }}$ instars larvae previously feed on leaves treated with the concentration of $\mathrm{LC}_{50}$ values of each of the tested insecticides (lufenuron and hexaflumuron). $10 \mu \mathrm{l}$ of the enzyme preparation was incubated with the

Table 1: Toxicity of IGRs on $S$. littoralis larvae.

\begin{tabular}{|c|c|c|c|c|c|c|c|c|}
\hline \multirow{4}{*}{ S. littoralis strains } & \multicolumn{8}{|c|}{$\mathrm{LC}_{50}(\mathrm{ppm})$} \\
\hline & \multicolumn{4}{|c|}{ lufenuron } & \multicolumn{4}{|c|}{ hexaflumuron } \\
\hline & \multicolumn{2}{|c|}{$24 \mathrm{hr}$} & \multicolumn{2}{|c|}{ 48hr } & \multicolumn{2}{|c|}{$24 \mathrm{hr}$} & \multicolumn{2}{|c|}{$48 \mathrm{hr}$} \\
\hline & $2^{\text {nd }}$ & $4^{\text {th }}$ & $2^{\text {nd }}$ & $4^{\text {th }}$ & $2^{\text {nd }}$ & $4^{\text {th }}$ & $2^{\text {nd }}$ & $4^{\text {th }}$ \\
\hline Lab & 0.31 & 0.44 & 0.052 & 0.061 & 0.55 & 0.78 & 0.068 & 0.077 \\
\hline Field & 0.54 & 0.63 & 0.071 & 0.080 & 0.76 & 0.97 & 0.095 & 0.096 \\
\hline
\end{tabular}

substrate for $30 \mathrm{~min}$, the enzyme-substrate mixture was used to measure the remaining activity. The percent inhibition was calculated using the following formula:

$\%$ Inhibition $=\frac{\mathrm{V}-\mathrm{Vi}}{\mathrm{V}} \times 100$

Where:-

(V) is the specific activity in larvae feed on treated castor leaves.

(Vi) is the specific activity in larvae feed on non treated castor leaves.

\subsection{In vitro inhibition of chitinase activity}

The inhibitor of chitinase activity was evaluated to determine enzyme kinetic parameters, the method of Dixon and Webb (1964) was adopted to draw the Dixon-plots by plotting $1 / \mathrm{V}$ versus concentrations of the inhibitor (lufenuron and hexaflumuron) at two concentrations of the substrate, chitin (the substrate of chitinase) concentrations of 3.0 and $5.0 \mathrm{mM}$. Estimation of $\mathrm{I}_{50}$ value was carried out by preincubating the enzyme with the inhibitor for 30 min, using the following concentrations $0.1 ; 1 ; 5$; $10 ; 50$, and $100 \mu \mathrm{M} . \mathrm{K}_{\mathrm{i}}$ (the inhibition constant) values for each inhibitor were estimated from Dixon-plot. Michaelies-Menten Kinetics $\left(K_{m}\right.$ and $\mathrm{V}_{\max }$ ) values were calculated by a linear regression of 6 point on each Lineweaver and Burk Plot (1934).

\section{RESULTS AND DISCUSSION}

\section{Toxicity of IGRs against $S$. littoralis larvae:}

The toxicity of the lufenuron and hexaflumuron in terms of $\mathrm{LC}_{50}$ are given in table (1) for $2^{\text {nd }}$ and $4^{\text {th }}$ larvae of $S$. littoralis. $\mathrm{LC}_{50}$ values were 0.31 and $0.55 \mathrm{ppm}$ for lufenuron and hexaflumuron respectively against $2^{\text {nd }}$ instar larvae of $S$. littoralis after $24 \mathrm{hr}$ for lab strain, while for field strain $\mathrm{LC}_{50}$ values were 0.54 and $0.76 \mathrm{ppm}$ for the two IGRs respectively. Also $\mathrm{LC}_{50}$ values were 0.052 and 0.068 ppm after $48 \mathrm{hr}$ for lab strain, while for field strain $\mathrm{LC}_{50}$ values were 0.068 and $0.095 \mathrm{ppm}$ for two IGRs, respectively. $\mathrm{LC}_{50}$ values were 0.44 and 0.78 ppm for lufenuron and hexaflumuron respectively against $4^{\text {th }}$ instar larvae of $S$. littoralis after $24 \mathrm{hr}$ for lab strain, for field strain $\mathrm{LC}_{50}$ values were 0.63 and $0.97 \mathrm{ppm}$ for the two IGRs respectively. $\mathrm{LC}_{50}$ values were 0.061 and $0.077 \mathrm{ppm}$ after $48 \mathrm{hr}$ for lab strain respectively, while for field strain $\mathrm{LC}_{50}$ values were 0.080 and $0.096 \mathrm{ppm}$ for two IGRs respectively.

$$
\Gamma \cdot \varepsilon
$$


According to $\mathrm{LC}_{50}$ values it is quite clear that the susceptibility of $S$. littoralis larvae to lufenuron and hexaflumuron decreased by increasing the posttreatment period. Also it was observed that the $2^{\text {nd }}$ instar was more susceptible than the $4^{\text {th }}$ instar. The present results are confirmed by the results of (Fisk \& Wright 1992; Toscano et al., 2001, and Sandeep \& Bhamare 2006).

The in vivo inhibition of $S$. littoralis chitinase activity:

The in vivo inhibitory effect of the $\mathrm{LC}_{50}$ values of tested IGRs against to the S. littoralis $2^{\text {nd }}$ and $4^{\text {th }}$ instars lab and field strains larval chitinase are shown in table (2). The data cleared that lufenuron and hexaflumuron concentration exhibited a high percentages of reduction of chitinase activity. The percentages of chitinase inhibition were 88.1 , and $74.5 \%$ for lab strain of $S$. littoralis $2^{\text {nd }}$ instar larvae, respectively, while in field strain values were 74.3 and $62.8 \%$ for the two IGRs respectively. Also the values were 73.6 , and $63.1 \%$ for lab strain of $S$ littoralis $4^{\text {th }}$ instar larvae, and for field strain the values were 61.9 , and $57.4 \%$ for the two IGRs respectively.

These results show that the tested IGRs act by reducing chitin incorporation in the cuticle of $S$ littoralis, similar results were obtained by Susan $e$ al., 1990. Properties of the IGRs were originally inappropriately timed and poorly coordinated moulting processes, the resulting perturbation of moulting and metamorphosis leads to death, usually because the insects cannot escape from the exuvie (Ascher \& Nemny 1979; Aller \& Ramsay, 1988, and Liburd et al., 2000). Therefore one may expect that these compounds will be very potent on cotton leafworm and other lepidopterous larvae.

\section{Kinetic parameters of chitinase inhibition:}

The kinetic studies were conducted to evaluate the effects of lufenuron and hexaflumuron on chitinase activity in both tested strains of $S$. littoralis $2^{\text {nd }}$ and $4^{\text {th }}$ larvae, table (3) shows the obtained Lineweaver-Burk (L-B) plots for chitinase in lab and field strains and the statistical analysis of the obtained values of $\mathrm{K}_{\mathrm{m}}$ (Michaelis-Menten kinetics, constant) and $\mathrm{V}_{\max }$ (maximum velocity) of the chitinase activity. The $\mathrm{K}_{\mathrm{m}}$ values for chitinase were generally higher for field strain than lab strain, the change in $K_{m}$ values of chitinase between the lab and field strains indicated changes in the affinities. recognized through their ability to initiate

The present results show that the $\mathrm{V}_{\max }$ values of chitinase may reflect the physiological importance of the chitinase in the function of the moulting of the $S$. littoralis larvae. The $\mathrm{V}_{\max }$ values were generally higher in field strains than lab strain, this indicated that the number of active sites on the chitinase of the larvae was increased in the field strain, such change may be followed by decrease in the insect susceptibility which could be altered by field application of the insecticides.

The in vitro inhibition of $S$. littoralis chitinase activity:

To characterize more details about the in vitro inhibition of chitinase by the inhibitors, the $K_{i}$ value of each inhibitor was estimated from the graphical method of Dixon and Webb (1964), table (4). The sensitivity of chitinase activity to lufenuron and hexaflumuron were measured by $\mathrm{I}_{50}$ values. In the case of lufenuron the $\mathrm{I}_{50}$ values were 0.31 , and 0.64 $\mu \mathrm{M}$ for lab and field strains of $S$. littoralis $2^{\text {nd }}$ larvae respectively, while $\mathrm{I}_{50}$ values were 0.44 , and 0.75 $\mu \mathrm{M}$ for lab and field strains of $S$. littoralis $4^{\text {th }}$ larvae respectively. Similarly, in case of the hexaflumuron the $\mathrm{I}_{50}$ values were 0.57 , and $0.76 \mu \mathrm{M}$ for lab and field strains of $S$. littoralis $2^{\text {nd }}$ larvae respectively, the $\mathrm{I}_{50}$ values were 0.65 , and $0.81 \mu \mathrm{M}$ for lab and field strains of $S$. littoralis $4^{\text {th }}$ larvae respectively. The $\mathrm{K}_{\mathrm{i}}$ values were 20 , and $35 \mu \mathrm{M}$ for lab and field strains of $S$. littoralis $2^{\text {nd }}$ larvae respectively, in case of lufenuron, while the values were 44 , and $50 \mu \mathrm{M}$ for lab and field strains of $S$. littoralis $4^{\text {th }}$ larvae respectively. Also, in case of hexaflumuron the values were 34 , and $51 \mu \mathrm{M}$ for lab and field strains of $S$. littoralis $2^{\text {nd }}$ larvae respectively, while the values were 52 , and $63 \mu \mathrm{M}$ for lab and field strains of $S$. littoralis $4^{\text {th }}$ larvae, respectively.

Chitinase plays an essential role during ecdysis. This enzyme is vital to moult in insects, and may also affect gut physiology through their involvement in peritrophic membrane turnover. The exoskeleton of insect might constitute a useful target site for insecticidal chemicals. The obtained changes in enzymes activity between lab and field strains may due to the variation in the protein synthesis as a response to the different treatment (Clarke \& Jewess 1990; Smagghe et al., 1997; Wilson \& Cryan 1997; Dean et al., 1999; Merzendorfer \& Zimoch, 2003, and Kostyukovsky \& Trostanetsky 2006).

Table 2: In vivo inhibition of $S$. littoralis larvae chitinase activity by two IGRs $\left(\mathrm{LC}_{50}\right)$.

$\%$ inhibition of chitinase activity

\begin{tabular}{lcccc} 
& \multicolumn{2}{c}{ lufenuron } & \multicolumn{2}{c}{ hexaflumuron } \\
\cline { 2 - 5 } S. littoralis & $\mathbf{2}^{\text {nd }}$ & $\mathbf{4}^{\text {th }}$ & $\mathbf{2}^{\text {nd }}$ & $\mathbf{4}^{\text {th }}$ \\
\cline { 2 - 5 } Strains & 88.1 & 73.6 & 74.5 & 63.1 \\
Lab & 74.3 & 61.9 & 62.8 & 57.4 \\
\hline
\end{tabular}


Table 3: Michaelies-Menten Kinetics of the chitinase of larval of S. littoralis.

\begin{tabular}{|c|c|c|c|c|c|c|c|c|}
\hline \multirow{3}{*}{$\begin{array}{l}\text { S. littoralis } \\
\text { Strains }\end{array}$} & \multicolumn{4}{|c|}{ lufenuron } & \multicolumn{4}{|c|}{ hexaflumuron } \\
\hline & \multicolumn{2}{|c|}{$\mathbf{K}_{\mathrm{m}} \mathbf{m M}$} & \multicolumn{2}{|c|}{$\mathbf{V}_{\max } \mathbf{m M}$} & \multicolumn{2}{|c|}{$\mathbf{K}_{\mathrm{m}} \mathbf{m M}$} & \multicolumn{2}{|c|}{ Vmax mM } \\
\hline & $2^{\text {nd }}$ & $4^{\text {th }}$ & $2^{\text {nd }}$ & $4^{\text {th }}$ & $2^{\text {nd }}$ & $4^{\text {th }}$ & $2^{\text {nd }}$ & $4^{\text {th }}$ \\
\hline Lab & 0.33 & 0.46 & 6.8 & 5.2 & 0.52 & 0.60 & 4.7 & 3.6 \\
\hline Field & 0.54 & 0.65 & 4.7 & 3.2 & 0.64 & 0.77 & 2.9 & 1.8 \\
\hline
\end{tabular}

Table 4: In vitro inhibition of $S$. littoralis larvae chitinase activity by two IGRs.

\begin{tabular}{|c|c|c|c|c|c|c|c|c|}
\hline \multirow{3}{*}{$\begin{array}{l}\text { S. littoralis } \\
\text { Strains }\end{array}$} & \multicolumn{4}{|c|}{ Lufenuron } & \multicolumn{4}{|c|}{ Hexaflumuron } \\
\hline & \multicolumn{2}{|c|}{$\mathrm{I}_{50} \mu \mathrm{M} / \mathrm{L} / \mathrm{min}$} & \multicolumn{2}{|c|}{$\mathbf{K}_{\mathrm{i}} \boldsymbol{\mu M}$} & \multicolumn{2}{|c|}{$\mathrm{I}_{50} \mu \mathrm{M} / \mathrm{L} / \mathrm{min}$} & \multicolumn{2}{|c|}{$\mathbf{K}_{\mathrm{i}} \boldsymbol{\mu M}$} \\
\hline & $2^{\text {nd }}$ & $4^{\text {th }}$ & $2^{\text {nd }}$ & $4^{\text {th }}$ & $2^{\text {nd }}$ & $4^{\text {th }}$ & $2^{\text {nd }}$ & $4^{\text {th }}$ \\
\hline $\mathrm{Lab}$ & 0.31 & 0.44 & 20 & 44 & 0.57 & 0.65 & 34 & 52 \\
\hline Field & 0.64 & 0.75 & 35 & 50 & 0.76 & 0.81 & 51 & 63 \\
\hline
\end{tabular}

Finally, according to the results presented lufenuron and hexaflumuron are potentially potent insecticides for controlling $S$. littoralis. These compounds are effective suppressors for the development of the entire life cycle of insects. They act preferentially by interfering with chitin synthesis metabolism (chitin synthesis inhibitors) and with the deposition of chitin in the insect cuticle. Therefore, these compounds could be used in the integrated pest management (IPM) programs, in order to minimize the negative effects of conventional insecticides on the environments and to protect the natural enemies.

1-Yield/vine:

Data in Table (1) clearly show that spraying elusters of Early sweet grapevines with $\mathrm{GA}_{3}$ at 10 to $40 \mathrm{ppm}$ or Sitofex at 2.5 to $10 \mathrm{ppm}$ was significantly effective in improving the yield relative to the check treatment. The promotion on the yield was accompanied with increasing concentrations of each plant growth regulator. Using $\mathrm{GA}_{3}$ at 10 to 40 was significantly preferable than using Sitofex at 2.5 to $10 \mathrm{ppm}$ in improving the yield. A slight and unsignificant promotion on the yield was attributed to increasing concentrations of $\mathrm{GA}_{3}$ from 20 to 40 $\mathrm{ppm}$ and Sitofex from 5 to $10 \mathrm{ppm}$. The maximum yield was produced on the vines that received one spray of $\mathrm{GA}_{3}$ at $40 \mathrm{ppm}$ but the best treatment from economical point of view was the application 0 $\mathrm{GA}_{3}$-at $20 \mathrm{ppm}$ (since no measurable promotion on the yield was recorded between 20 and $40 \mathrm{ppm}$ of $\left.\mathrm{GA}_{3}\right)$. Under such promised treatment, yield/ vine reached 13.6 and $14.0 \mathrm{~kg}$ during both seasons, respectively. The control vines produced 9.1 and 9.6 $\mathrm{kg}$ during 2013 and 2014 seasons, respectively. The percentre of incress on the vield due to application of $\mathrm{GA}_{3}$ - at $20 \mathrm{ppm}$ over the check treatment reached 49.5 and $45.8 \%$ during both sens, respectively. The beneficialeffects of $\mathrm{GA}_{3}$ on the yield might be attributed to their positive action on increasing cluster weight. The promoting effects of $\mathrm{GA}_{3}$ - on the yield was supported by the restlts of Dimorska al., (2011) and Abu-Zahra and Salameh (2012) on different grapevine cvs.
The results regarding the beneficial effects off Sitofex on enhancing the yield are in harmony with those obtained by Juan et al. (2009); Abdel- Fattap etal., (2010) and Al Obeed (2011).

2-Harvesting date:

It is clear from the data in Table (1) that all GA and Sitofex treatments had significantly delayed op the harvesting date of Early Sweet grapevines rather than the control treatment. The degree of delayness on harvesting date was correlated to the increase of the concentrations of both $\mathrm{GA}_{3}$ and Sitefex. Usin $\mathrm{GA}_{3}$ signifieantly delayed havesting date comparing with using Sitofex. Increasing concentrations of $\mathrm{GA}_{3}$ from 20 to 40 ppm an Sitofex form 5 to $10 \mathrm{ppm}$ failed to show significant delay on harvesting date. A considerable advancement on harvesting date was observed of untreated vines the great delay on harvesting date was observed on the vines that received $\mathrm{GA}_{3}$-at $4 p$ ppm during both seasons. $\mathrm{GA}_{3}$ and Sitofex wer shown by many authors to retard the release of ethylene and the disappearance of pigments such as chlorophylls and carotenoids and onest of maturit start. Also they were responsible for prolonging pre maturity stages Nickell (1985). These result regarding the delaying effect of $\mathrm{GA}_{3}$-and Sitofex op harvesting date were in harmony with those ebtained by Wassel et al., (2007), Kassem et at. (2011), Abu-Zahra and Salameh (2012) and Refa t et al. (2012).

3-Cluster weight and dimensions:

It is evident from the data in Table (1) thdt treating clusters with $\mathrm{GA}_{3}$ at 10 to $40 \mathrm{ppm}$ or Sitofex at 2.5 to $10 \mathrm{ppm}$ was significantl accompanied with enhancing weight, length and width of eluster relative the control treatment. 
$r \cdot V$ 
The promotion was significantly associated with increasing concentrations of $\mathrm{GA}_{3}$ and Sitofex. Usin $\mathrm{GA}_{3}$ was significantly favourable than using Sitofe in this respect. The maximum values were recordel on the vines that received one spray of $\mathrm{GA}_{3}$ at $4 p$ ppm. Meaningless promotion was detected with increasing concentrations of $\mathrm{GA}_{3}$ from 20 to 40 ppp 
and Sitofex from 5 to $10 \mathrm{ppm}$. The untreated vines produced the minimum values during both seasens. The positive ation of $\mathrm{GA}_{3}$-on-cluster weight ane dimensions might be attributed to its essential role on stimulating cell division and enlargement of eells, the water absorption and the biosynthesis 0 proteins which will lead to increase berry weight Dimovska et al., (2011); Abu-Zahra and Salameh, (2012) and Dimovska et al., (2014).

The previous essential rele of CPPU on eluste weight was attributed to its higher content $\theta$ eytokinin when applied to plants (Nickell, 1985).

\section{4-Shot berries \%}

Data in Table (2) obviously reveal that percentage of shot berries in the clusters of Early Sweet grapevines was significantly controlled with spraying $\mathrm{GA}_{3}$ at 10 to 40 ppmor Sitofex at 2.5 to 10 ppm relative to the check treatment. Using $\mathrm{GA}_{3}$ was preferable than using Sitofex in reducing the percentages of shot berries. There was a gradua reduction on the percentage of shot berries with increasing concentrations of $\mathrm{GA}_{3}$ and Sitofex. There was a slight reduction on such unfavourable phenomenon with increasing concentrations of GA form 20 to $40 \mathrm{ppm}$ and Sitofex from 5 to $10 \mathrm{ppm}$. The minimum values of shot berries (7.3 and $6.9 \%$ during both seasons, respectively) were recorded on the clusters harvested from vines treated with GA at $40 \mathrm{ppm}$. The maximum values of shot berries $(12.0 \& 12.5 \%)$ during both seasons were recorded on the untreated vines during both seasons. The reducing effect of $\mathrm{GA}_{3}$ - on shot berries might be attributed to its important role on enhancing cell division and the biosynthesis of proteins Nickell (1985). These results were supported by the results of wassel et al. (2007) and Abu-Zahra and Salameh (2012).

\section{5- Fruit quality:}

Data in Tables (2, $3 \&$ \& 4$)$ clearly show that spraying clusters with $\mathrm{GA} 3$ at 10 to $40 \mathrm{ppm}$ of Sitefex at 2.5 to 10 ppm significantly was accompanied with enhancing weight, longitudina and equatorial of berry, total acidity $\%$, proteins $\%$ and percentages of $\mathrm{P}, \mathrm{K}$ and $\mathrm{Mg}$ and T.S.S. \%, redueing sugars \%, T.S.S. I acid and totat carotenoids relative to the check treatment. The effect either increase or decrease was associated with increasing concentrations of each atwin. Using $\mathrm{GA}_{3}$ - sionificantly changed these parameters than using Sitofex. A slight effect was recorded on these quality parameters with increasing concentrations $\theta$ $\mathrm{GA}_{3}$ from 20 to 40 pm and Sitofex from 5 to 10 ppm. From economical point of view, the best results with regard to fruit quality were observed due to treating clusters with $\mathrm{GA}_{3}$ at $20 \mathrm{ppm}$ Untreated vines produced mnfavourable effects on fruit quality. These results were true during both seasons. The effect of $\mathrm{GA}_{3}$ on increasing berry weight and dimensions might be attributed to its effect in promoting cell division and enlargement of eells, water mptake and the biosynthesis of proteins Nickell (1985). These results were in concordance with those obtained by Williams and Ayars (2005) and Dimovska et al., (2014).

The higher content of Sitofex from cytokinins surly reflected on enhancing cell division and the elongation of berries Nickell (1985). These results were in agreement with those obtained by $\mathrm{Abu}$ Zahra (2013) and Retamales et (2015).

\section{CONCLUSION}

Treating Early Sweet grapevines once when the average berries reached $6 \mathrm{~mm}$ with $\mathrm{GA}_{3}$-at $20 \mathrm{ppm}$ was responsible for promoting yield and fruit quality.

\section{REFERENCES}

Abbott, W. S. (1925). A method for computing the effectiveness of an insecticide. J. Econ. Entomol. 18: 265-267.

Aller, H. F., and Ramsay, J. R. (1988). Rh-5849-A novel insect growth regulator with a new mode of action. Proceedings of the Brighton Crop Protection Conference, Pests and Diseases. 2: 511-518.

Andrew, C. C.; Mayer, R. T., and De-loach, J. R. (1982). Purification and characterization of chitinase from the stable fly Stomoxys calciteans. Arch. Biochem. Biophysiol. 216: 314- 321.

Ascher, K. R. S., and Nemny, N. E. (1979). Toxcicity of chitin synthesis inhibitors diflubenzuron and its dichlorobenzoyl analogue to Spodoptera littoralis larvae, Pestic. Sci. 7: 19.

Clarke, B. S., and Jewess, P. J. (1990). The inhibition of chitin synthesis in Spodoptera littoralis larvae by flufenoxuron, teflubenzuron and diflubenzuron. Pestic. Sci. 28: 377-388.

Dean, S. R.; Meola, R. W.; Meola, S. M., SittertzBhatkar, H., and Schenker, R. (1999). Mode of action of lufenuron in adult Ctenocephalides felis (Siphonaptera: Pulicidae). J. Med. Entomol. 36: 486-492.

Deul, D. H.; De-Jong, B. J., and Kortenbach, J. A M. (1978). Inhibition of chitin synthesis by two 1-(2,6-disubstitut benzoyl)-3-phenylurea insecticides. Pestic Biochem. and Physiol. 8: $98-105$.

Dixon, M., and Weeb, E. C. (1964). Enzymes. Academic press. Inc., New York. $2^{\text {nd }}$ Edition. 328-330.

Finney, D. J. (1971). Probit analysis, $3^{\text {rd }}$ edn, Cambridge Univ. Press, Cambridge, England. pp: 318.

Fisk, T., and Wright, D. J. (1992). Speed of action and toxicity of acylurea insect growth 
regulators against Spodoptera exempta (Walk.) and Spodoptera littoralis (Boisd.) larvae: Effect of intomult age. Pestic. Since. 35: 331-337.

Kostyukovsky, M., and Trostanetsky, A. (2006). The effect of a new chitin synthesis inhibitor, novaluron, on various developmental stages of Tribolium castaneum (Herbst). J. Stored Prod. Res. 42: 136-148.

Liburd, E. O.; Funderburk, J. E., and Olson, S. M. (2000). Effect of biological and chemical insecticides on Spodoptera species (Lep. Noctuidae) and marketable yield of tomatoes. J. of Applied Entomol. 124: 19-25.

Lineweaver, H., and Burk, D. (1934). The determination of enzyme dissociation constants. J. Amer. Chem. Soc. 56: 658.

Lowery, O. H.; Rosebrough, N. J.; Farry, A. L., and Randall, R. J. (1951). Protein measurements with folin phenol reagent. J. Bio. Chem. 193 265-271.

Merzendorfer, H., and Zimoch, L. (2003). Chitin metabolism in insects: structure, function and regulation of chitin synthases and chitinases. The J. Exp. Biol. 206: 4393-4412.

Reissig, J. L.; Strominger, J. L., and Leloir, L. F (1955). A modified colorimetric method for the estimation of $\mathrm{N}$-acetylamine sugers. J. Biol. Chem. 217: 959-966.

Sandeep, D. Gaikwad, and Bhamare, K. V. (2006) Efficacy of newer insect growth regulators and insecticides against cotton leafworm. J. Plant Sci. 1: 104-106.

Schneider, M.; Smagghe, G., and Vifiuela, E. (2003). Susceptibility of Hyposoter didymator (Hymenoptera: Ichenumonidae) adults to several IGRs pesticides and spinosad by different exposure methods. IBOC/wprs Bull. 26: 111-122.

Smagghe, G.; Auda, M.; Laecke, K., and Van Degheele, D. (1997). Significance of penetration and metabolism on topical toxicity of diflubenzuron in Spodoptera littoralis and Spodoptera exigua. Entomol. Exp. Et Applicata. 82: 255-260.

Susan, A. Lee; Barry, S. Clarke; Donald, W. Jenner, and Francis, A. Williamson. (1990). Cytochemical demonstration of the effects of the acylureas flufenoxuron and diflubenzuron on the incorporation of chitin into insect cuticle. Pestic. Sci. 28: 367-375.

Temerak, S. A. (2002). History records of field cotton leafworm (Spodoptera littoralis) resistance to conventional insecticides as influenced by the resistance programs in Egypt. Resistant Pest Management Newsletter. 12: 7 10
Toscano, N.; Prabhaker, N.; Castle, S. J., and Henneberrt, T. J. (2001). Interregional differences in baseline toxicity of Bemisia argentifolii (Homoptera: Aleyrodidae) to the two insect growth regulators, buprofezin and pyriproxyfen. J. Econ. Entomol. 94: 1538-1546.

Ware, G. W. (2000). The Pesticide Book, $5^{\text {th }}$ Ed. Thomson Publications, Fresno, California.

Wilson, T. G., and Cryan, R. J. (1997). Lufenuron, a chitin synthesis inhibitor interrupts development of Drosphila melanogaster. J. Exp. Zool. 278: 37-44.

Abdel-Fattah, M.E.; Amen, K.A.; Alaa, A.B. and Eman, A.A. (2010). Effect of berry thinnind, EPPU spraying and pinching on cluster an berry quality of two grapevine cultivar. Assiut J. of Agric. Sci., 40(4): 92-107.

Abu-Zahra, T.R. (2013). Effect of plant hormones application methods on fruit quality of Superior seedless grape. Bioscience Biotechnology Research Asia Vol. 10(2) 527-531.

Abu-Zahra, T.R. and Salameh, N. (2012). Influence of Gibebrellic acid and cane girdling on berr size of Black Magic grape cultivar. Middle East Journal of Scientific Research 11(6): 718-722.

Al-Obeed, R.S. (2011). Enhancing the shelf life an storage ability of Flame seedless grapevine by agrochemicals preharvest foliar applications. Middle East Journal of Scientific Research 8(2):319-327.

Association of Official Agricultural Chemists (A.O.A.C.) (2000). Official Methods of Analysis (A.O.A.C), 12 th Ed., Benjamin Franklin Station, Washington-D.C., U.S.A. pp. $490-510$.

Dimovska, V.; Ivanova, V.; Ilieva, F. an Sefijanova, E. (2011). Influence of bioregulator gibberellic acid on some technological characteristics of cluster and berry from some seedless grape varietie. Journal of Agric. Seience and technology $\mathrm{BI}$ 1074-1058.

Dimovska, V; Petropulos, V.I.; Salamovska, A. an Hieva, F. (2014). Flame seedless grape variety (Vitis vinifera L.) and different concentration of gibberellic acid (GA3). Bulgarian Journal of Agric. Sei., 20-No.1 $137-142$.

Dokoozlian, N.K. (2001). Gibberellic acid applied ot bloom reduces fruiit set and improves size of "Crimsen seelless" Table grapeHort.science 36(4): 706-709.

Guiseppe; F.; Andream, M.; Guiseppe, N. CarmelP. Angela, M.; Is bella, C. Piero, Mi,

r. 
Mariangela, V. and Vito, G. (2014). Girdling, Gibberellic acid, and forchlorfenuren-effect vield, quality and metabolic profile of table grape $\mathrm{cv}$. Italia. Am. J. Enol. Vitic. 65.3.

Hiscox, A. and Isralstam B. (1979). Method for the extraction of chlorephylls from leaf tissue without maceration. Can. J. Bot. 57: 1332 1334.

Juan, P.Z.; Bernardo, A.L. and Paulina, N. (2009) Preharvest applieations of grow regulators and their effect on postharvest quality of table grapes during cold storage. Postharvest Biology and technology 51.183 192.

Kassem, H.A.; Al Obeed, R.S. and Soliman, S. S.

(2011). Improving yield, quality and profitability of Flame seedless grapevine grown under arid envirenmental by growth regulators preharvest applications. Middle East Journal of Scientific research 8 (1): 165 172.

Lane, J. H. and Eynon, L. (1965). Determination of reducing sugars by means of Fehlings solution with methylene blue as indicator A.O.AC. Washington D.C.U.S.A. pp. 490 510.

Leopold, A. C. (1964). Plant growth and development. pp. 133-143.TATA McGraw Hill publishing Comp. LTD. Bombay New Delhi.

Marzouk, H.A. and Kassem, H.A (2011). Improving yield, quality and shelfe life of Thompson seedless grapevine by preharvest foliar application. Scientia Horticulruea 130:425 430.

Mead, R.; Currnow, R. N. and Harted, A. M.(1993)
Statistical Biology. 2"d Ed. Methods in Agriculture and Experimental and Hall, Londen pp. 1020

Nickell, L.G. (1985). New plant growth regulator increase grape size. Proc. Plant growth reg. Soc. of Am. 12.17.

Refaat, S.S.E.; Ghada, Sh.Sh. and Ola, A.A.(2012), Effect of foliar spraying with gibberllic acid and/ or sitofex on bud behaviour, vegetative growth, yield and cluster quality of Thompson seedless grapevines. Journal of American Science, 8 (5): 99: 21-34.

Retamales, J.; Bangerth, F. Cooper, T. and-Callejas, R. (2015). Effect of $C P P U$ and $G A 3$ on fruit quality of Sultanina table grape. Ishs Acta Hoerticulturae 394: plant Bioregulators in Horticulture.

Wassel, A.H.; Abdel Hameed, M. Gobara, A and attia, M. (2007). Effect of some micronuitrients, gibberellic acid and ascorbic acid on growth, yield and quality of white Banaty seedless grapevines. African Crop Science Conference Proceeding Vol. 8 p. 547-553.

Weaver, R. J.(1976). Grape Growing . A Wiley Interscience Puplication John Wiley \& Davis. New York. London. Sydney. Tronto. Pp 160 175.

Wilde, S. A.; Corey, R. B.; Lyer, I. G. and Voigt, G. K. (1985). Soil and Plant Analysis for Tree Eulture. $3^{\text {rd }}$-Oxford \& IBH publishing $\mathrm{CO}$., New Delhi, pp. $1-218$.

Williams, L.E. and Ayars, J.E. (2005). Water use of Thompson-seedless grapevines as affected by the application of Gibberellic acid $\left(\mathrm{GA}_{3}\right)$ and trunk girdling practices to increasing Berry size. Agriculture and Forest Meterology, 129. $85-94$ 


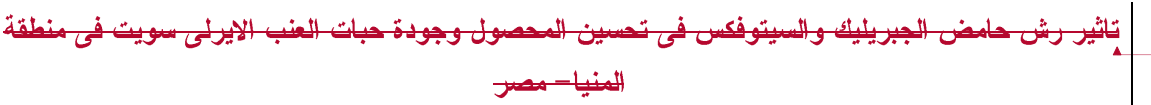

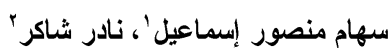

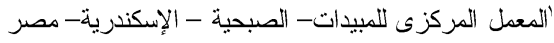

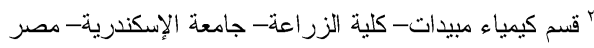

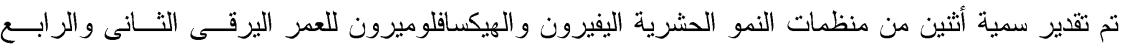

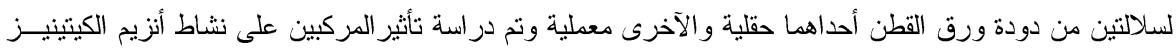

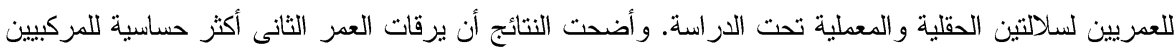

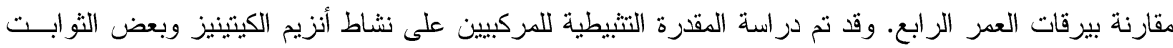

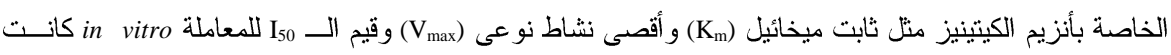

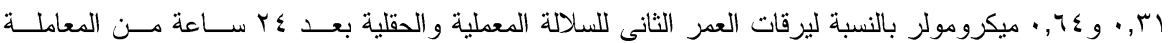

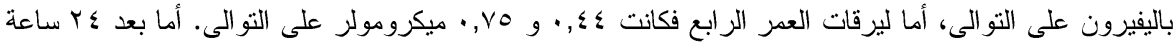

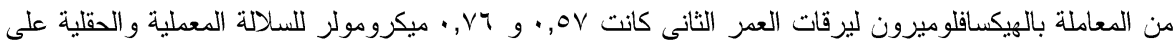

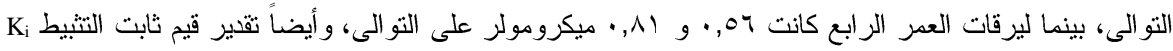

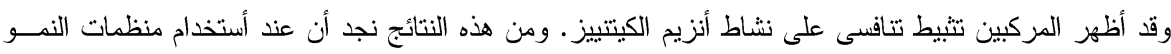

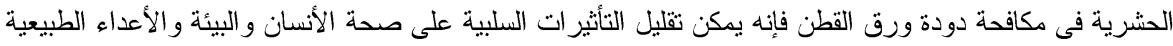
وتفادى زيادة مقاومة هذه الآفة لفعل المبيدات التقليدية.
Formatted: Font: 12 pt, Complex Script Font: $12 \mathrm{pt}$

Formatted: Font: Not Bold, Complex Script Font: Traditional Arabic, Not Bold 